\title{
Clinical Audit on Sedation in Mechanically Ventilated Child
}

\author{
ASMAA H. SHOREIT, M.D.; MOHAMED A. FATHY, M.D. and MAHMOUD K. AHMED, M.Sc. \\ The Department of Pediatrics, Faculty of Medicine, Assiut University, Assiut, Egypt
}

\begin{abstract}
Background: Sedation is a necessary component in the care of all critically ill patients, especially those requiring mechanical ventilation to prevent asynchronous ventilation, improve oxygenation, and prevent inadvertent extubation.

Patients and Methods: Data of 100 children (1m-18y) age receiving mechanical ventilation in pediatric intensive care unit of Assiut University Children Hospital during period of six months from April 2016 to October 2016 is collected and analyzed and is compared with the standard guidelines according to American Association of Critical Care (2012) as a reference standard in sedation in mechanically ventilated child.

Results: Midazolam is the most common drug used by $(70 \%)$ of cases. Monitoring of sedation by sedation assessment scale (simplified COMFORT scale) done only for (30\%) of cases.

Conclusion: We need to stick with the international guidelines as a reference standard to facilitate the correct selection of drugs, their appropriate administration and careful monitoring, improve the quality of sedation and avoid their adverse effects.
\end{abstract}

Key Words: Sedation - Mechanical ventilation - Intensive care unit.

\section{Introduction}

SEDATION is a necessary component in the care of all critically ill patients, especially those requiring mechanical ventilation to prevent asynchronous ventilation, improve oxygenation, and prevent inadvertent extubation [1,2]. An ideal sedative agent would have rapid onset of action, be effective at providing adequate sedation, allow rapid recovery after discontinuation, be easy to administer, lack drug accumulation, have few adverse effects, interact minimally with other drugs [3].

Optimal sedation is described as a level of sedation at which the patient is sedated but easily

Correspondence to: Dr. Mahmoud K. Ahmed E-Mail: mahmoudkotb27@gmail.com rousable, free from pain and anxiety, and could tolerate nursing and medical procedures. Achieving optimal sedation may help to avoid risks associated with oversedation (e.g., prolonged MV and extubation failure) and problems of undersedation (e.g., agitation, anxiety-induced hypertension, and unplanned extubation). Suboptimal sedation may potentially prolong length of stay (LOS) in PICU and lead to increased morbidity and may increase health care costs [4].

The aim of this study is:

- To facilitate the correct selection of drugs, their appropriate administration and careful monitoring.

- To improve the quality of sedation and avoid their adverse effects.

- To shorten the length of stay in hospital.

- To assess how much the adapted protocol of sedation for mechanically ventilated child is applied in PICU AUH in comparison with standard guidelines according to American Association of Critical Care (2012) as a reference standard in Sedation in Mechanically Ventilated Child.

\section{Patients and Methods}

Clinical audit on sedation in critically ill children receiving mechanical ventilation one month to eighteen years of age admitted to pediatric intensive care unit of Assiut university children hospital (From April 2016 to October 2016).

Inclusion criteria:

- Mechanically ventilated child.

- Age 1 month - 18 years.

\section{Abbreviations}

PICU: Paediatric intensive care unit.

MV : Mechanical ventilation.

LOS : Length of stay.

AUH: Assiut university hospital. 


\section{Exclusion criteria:}

- Neonates.

- Patients with traumatic brain injury.

- Patients with status epilepticus.

- Comatosed patients.

\section{Results}

Our study was conducted on children receiving mechanical ventilation in pediatric intensive care unit of Assiut university children hospital during six months from From April 2016 to October 2016. Our study included 100 cases $40 \%$ of cases were below the age of 1 years while $30 \%$ were $1-5$ years age group. According to the sex of the studied cases, $54 \%$ were females and $46 \%$ were males.

Table (1): Methods of administration.

\begin{tabular}{lccc}
\hline $\begin{array}{l}\text { Methods of } \\
\text { administration }\end{array}$ & $\begin{array}{c}\text { Number } \\
(\mathrm{N}=100)\end{array}$ & Percentage \\
\hline Intermittent & 10 & & 10 \\
Continuous & 90 & & 90 \\
Continuous & & $\mathrm{N}=90$ & \\
Loading dose: & & & \\
$\quad$ Yes & 75 & & 83.3 \\
$\quad$ No & 15 & & 16.6 \\
Accuracy of loading dose: & & $\mathrm{N}=75$ & \\
$\quad$ Accurate & 70 & & 93.3 \\
$\quad$ Not accurate & 5 & & 6.6 \\
Titration of loading dose: & & $\mathrm{N}=75$ & \\
$\quad$ Yes & 45 & & 60 \\
$\quad$ No & 30 & & 40 \\
Maximum loading dose: & & $\mathrm{N}=75$ & \\
$\quad$ Yes & 10 & & 13.3 \\
$\quad$ No & 65 & & 86.6 \\
Addition of another drug: & & $\mathrm{N}=75$ & \\
$\quad$ Yes & 15 & & 20 \\
$\quad$ No & 60 & & 80 \\
\hline
\end{tabular}

Table (2): Methods of administration (continue).

\begin{tabular}{|c|c|c|}
\hline $\begin{array}{l}\text { Continuous } \\
\text { maintenance dose }\end{array}$ & $\begin{array}{c}\text { Number } \\
(\mathrm{N}=90)\end{array}$ & Percentage \\
\hline Accuracy of maintenance dose: & \multicolumn{2}{|c|}{$\mathrm{N}=90$} \\
\hline Accurate & 90 & 100 \\
\hline Not accurate & 0 & 0 \\
\hline Titration of maintenance dose: & \multicolumn{2}{|c|}{$\mathrm{N}=90$} \\
\hline Yes & 64 & 71.1 \\
\hline No & 26 & 28.8 \\
\hline Maximum maintenance dose: & \multicolumn{2}{|c|}{$\mathrm{N}=90$} \\
\hline Yes & 10 & 11.1 \\
\hline No & 80 & 88.9 \\
\hline Addition of another drug & \multicolumn{2}{|c|}{$\mathrm{N} \equiv 90$} \\
\hline Yes & 6 & 6.6 \\
\hline No & 84 & 93.3 \\
\hline
\end{tabular}

Table (3): Side effects of sedative drugs.

\begin{tabular}{|c|c|c|}
\hline & $\begin{array}{l}\text { Number } \\
(\mathrm{N}=100)\end{array}$ & Percentage \\
\hline Side effects of sedation: & & \\
\hline Present & 10 & 10 \\
\hline Abscent & 90 & 90 \\
\hline Mangment of side effects: & \multicolumn{2}{|c|}{$\mathrm{N}=10$} \\
\hline Dose reduction & 7 & 70 \\
\hline Drug change & 3 & 30 \\
\hline
\end{tabular}

Table (4): Withdrawal of sedative drugs.

\begin{tabular}{|c|c|c|}
\hline & $\begin{array}{c}\text { Number } \\
(\mathrm{N}=46)\end{array}$ & Percentage \\
\hline \multicolumn{3}{|l|}{ Withdrawal of sedation: } \\
\hline Accurate & 39 & 84.7 \\
\hline Not accurate & 7 & 15.2 \\
\hline Withdrawal symptoms: & \multicolumn{2}{|c|}{$\mathrm{N}=10$} \\
\hline Yes & 2 & 4 \\
\hline No & 44 & 95.6 \\
\hline
\end{tabular}

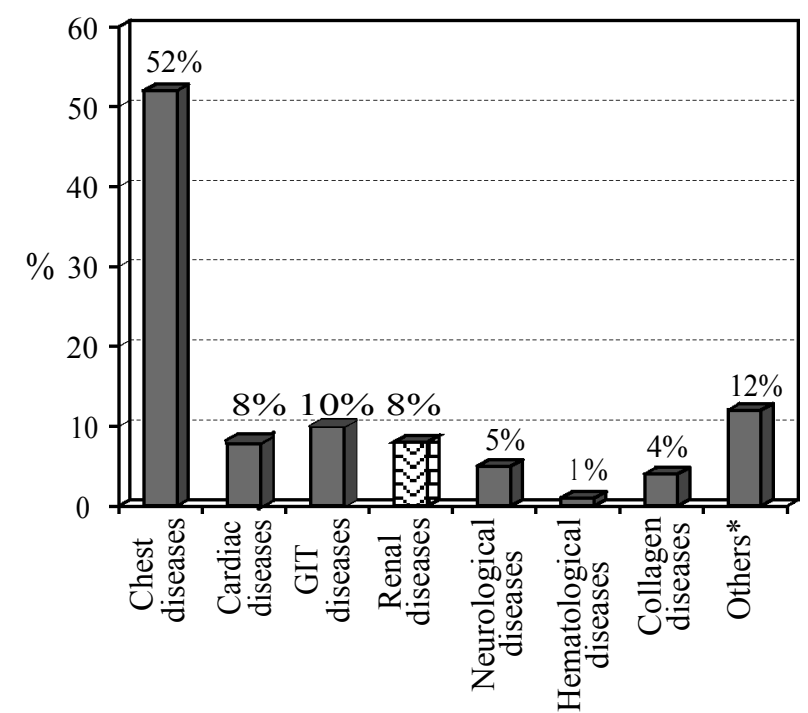

Fig. (1): Indications of connection to mechanical ventilat ionamong the studied cases.

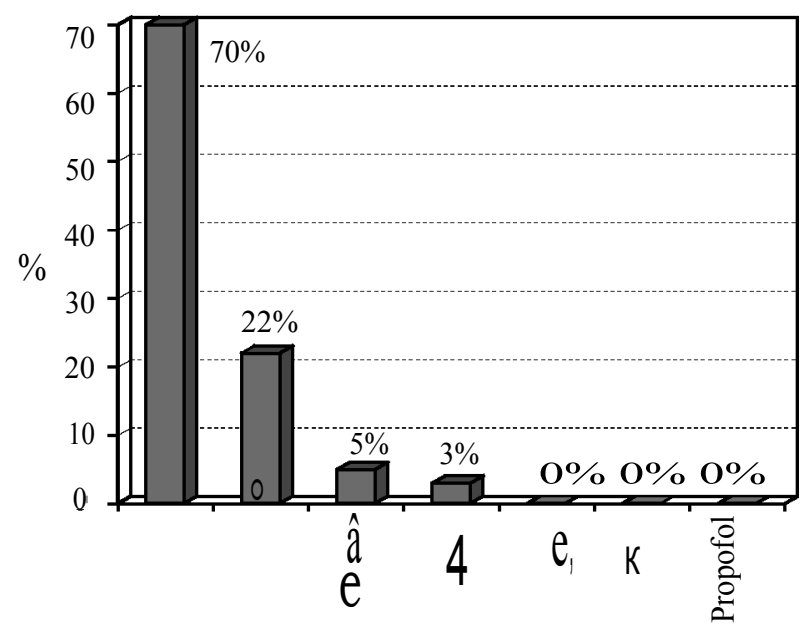

Fig. (2): The common drug used for sedation. 
Sedation simplified COMPFORT scale

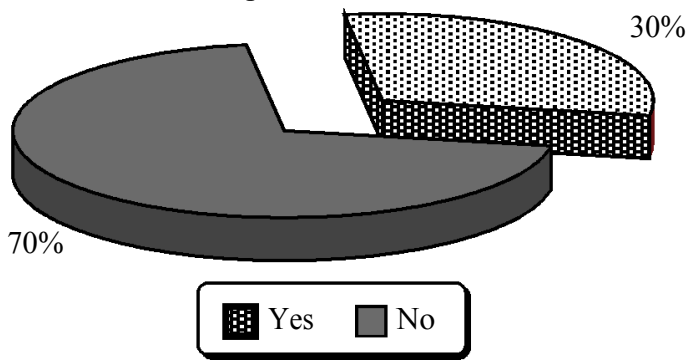

Fig. (3): Monitoring of sedation by simplified COMFORT scale.

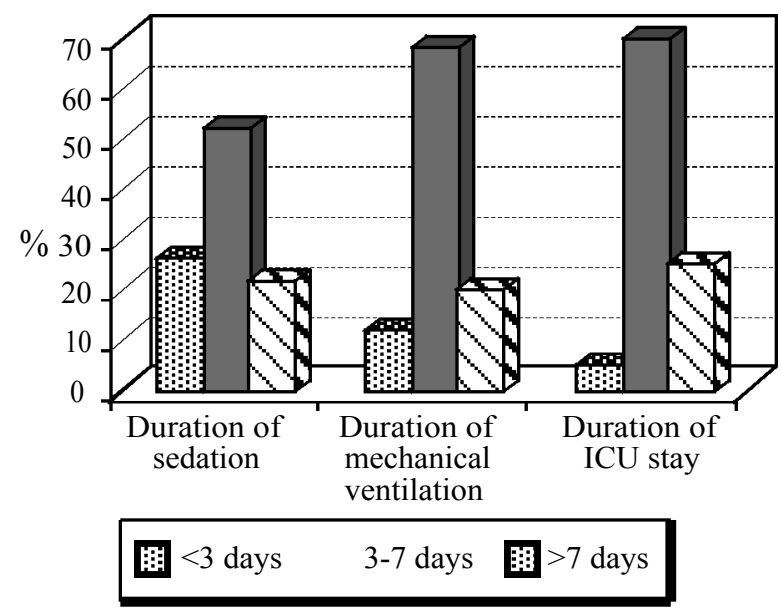

Fig. (4): Duration of sedation.

\section{Discussion}

According to sedation protocol for mechanically ventilated child in PICU of AUH:

Our study included (100) patients reciveing mechanical ventilation in pediatric intensive care unit of Assiut University Children Hospital. Their age ranged from (1) month to (18) year, 46 cases were males and 54 were females.

- Any correctable environmental and physical factors causing discomfort must be corrected before starting of sedative drugs (in our study done for all cases).

- The selection of the drug depends on several factors, such as age, disease, and organ dysfunction/failure (in our study Midazolam is the most common drug used by $(70 \%)$ of cases and this agreemrnt with (Twite et al., 2004) [5]. And their is defect in avalabilty of some drugs as Ketamine, Propofol and Dexmedetomidine.

- According to method of administration of sedative drugs accurate loading dose shoud be given for induction of sedation in our study 75 cases recived loading dose with accuracy $(90 \%)$.

- Monitoring of sedation by cardiopulmonary monitoring (HR, BP, ECG monitoring) and sedation assessment scale (simplified COMFORT scale). (in our study cardiopulmonary monitoring done for most of cases but only (30\%) of cases monitored by Simplified COMFORT Scale.

- Side effects of each sedative drug recorded and mangement if present by dose reduction or change the drug by another (in our study it was found that side effects as hypotension and bradypnea present in (10) cases managed by dose reduction in (7) cases while drug changed in (3) cases).

- Accurate withdrawal of sedative drugs (in our study Drug withdrawal done for (46) cases with accuracy $(84.7 \%)$ and Withdrawal symptoms are present in $(4 \%)$ of this cases .

\section{Conclusion:}

There is wide variety of pharmacological agents are now available for sedation such as Benzodiazepines, Chloral hydrate, Ketamine, Barbiturates, Propofol, Central a2-agonists (Clonidine Dexmedetomidine). Despite the fact that there are a wide variety of drugs with different indications, there is no sedative that suits all situations [6].

Despite their widespread use, sedative drugs still lack data supporting appropriate dosing, safety, and efficacy of combination therapies, and optimal drug regimens for sedation during mechanical ventilation. The selection of the drug depends on several factors, such as age, disease, and organ dysfunction/failure [7].

\section{References}

1- JOHNSON, et al.: AACNAdvanced Critical Care Volume 23, Number 4, Pp. 415-434, 2012.

2- PLAYFOR S.D., THOMAS D.A. and CHOONARA I.: Sedation and neuromuscular blockade in paediatric intensive care: A review of current practice in the UK. Paediatric Anaesthia, 13: 147-51, 2003.

3- OSTERMANN M.E., KEENAN S.P., SEIFERLING R.A., et al.: Sedation in the Intensive Care Unit. A Systematic Review. JAMA, 283 (11): 1451-1459, 2000.

4- VET N.J., ISTA E., de WILDT S.N., et al: Optimal sedation in pediatric intensive care patients: A systematic review. Intensive. Care. Med., 39: 1524-1534, 2013.

5- TWITE M.D., RASHID A., ZUK J. and FRIESEN R.H.: Sedation, analgesia, and neuromuscular blockade in the pediatric intensive care unit: Survey of fellowship training programs. Pediatr. Crit. Care. Med., 5: 521-32, 2004.

6- VENDER J.S., SZOKOL J.W., MURPHY G.S. and NITSUN M.: Sedation, analgesia, and neuromuscular blockade in sepsis: An evidencebased review. Critical. Care. Med., 32 (11 Suppl): S554-61, 2004.

7- ZUPPA A.F., ADAMSON P.C., MONDICK J.T., et al.: Drug utilization in the pediatric intensive care unit: Monitoring prescribing trends and establishing prioritization of pharmacotherapeutic evaluation of critically ill children. J. Clin. Pharmacol., 45: 1305-1312.7., 2005. 


\section{دراسة تدقيقية اكلينيكية عن تهدئة الطفل على الطيك جهاز التهوية المينيكيكانيكية}

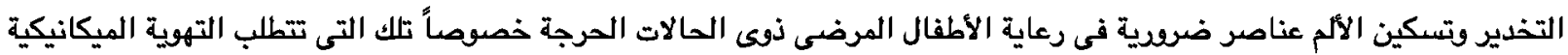

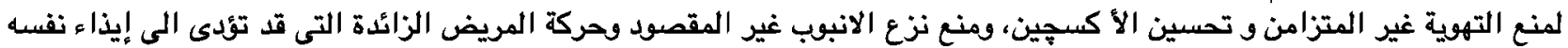
مما يترتب عنه ضرر جسدى ومضاعفات نفسية.

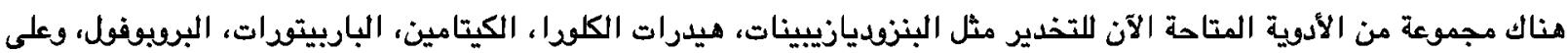

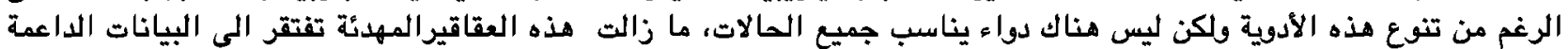

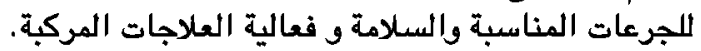

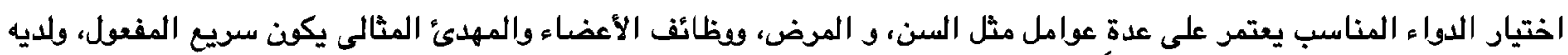

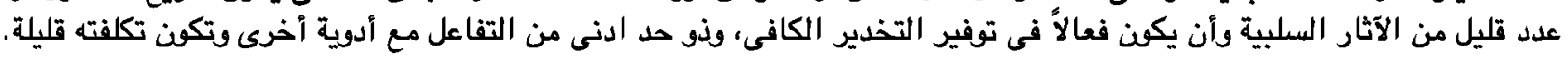

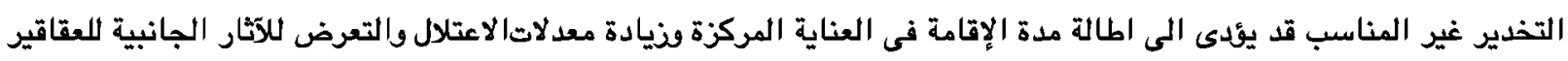

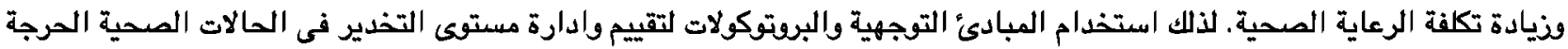
للأطفال قد تصسن من كفاءة الرعاية وتخفف من تكاليف الرعاية الصحية لهم.

الهدف من الدراسة : الهدف من هذه الدراسة هو تقييم استخدام العقاقير المهدئة فى الأطفال الممابين بأمراض خطيرة ويتلقون التهوية

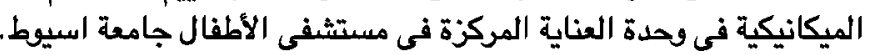
معايير الأشتمال:

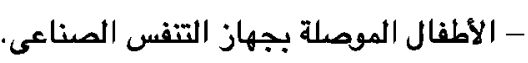

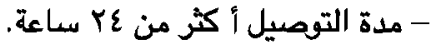

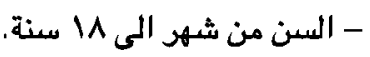

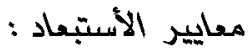

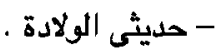

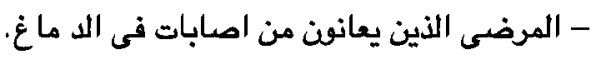

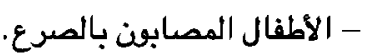
- المرضى المصابين بغييوية.

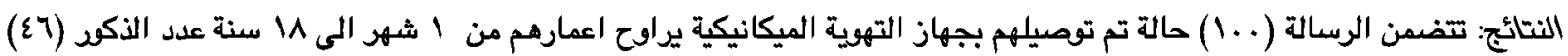
حالة وعدد الإناث (عه) حالة.

وأظهرت بياتات الدراسة : أكثر الإراض التى تطلبت توصيل المريض بجهاز التهوية الميكانيكية هى امراضالمدر بنسبة (ro٪). عقار الميدازولام هو أكثر العقاقير المستخدمة ف تهئة الأطفال المتصلين بجهاز التهوية الميكانيكية بنسبة (.V\%) ويليه عقار الكيتا مين

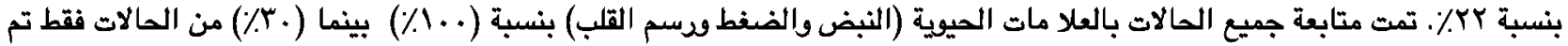
فيهم استخدام قياس مستوى تهدئة الطفل المستخدم العقار المهات المهاتئ.

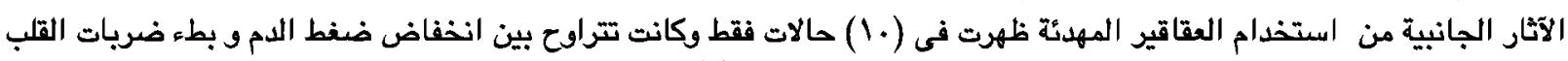

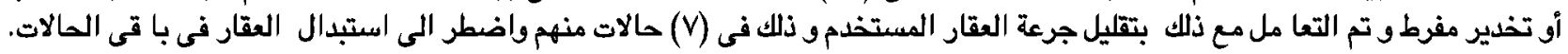
التوصيات: ا- ينصح باستخدام بروتوكول التخدير فى وحدة العناية المركزة للأطفال والذهى يساهم في تيسير الأختيار الصحيح العقا قير الههئة وتخسين نوعية التخدير وتجنب الآثار الضارة. r- جرعات الأدوية المستخدمة يجب ان تكنف موثثة مع امكانية زيادة تدريجية فى جرعات العقاقير للوصول للمستوى المطلوب من التخدير.

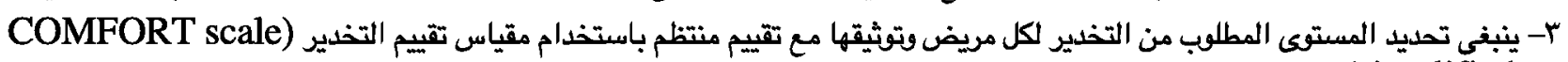
.(simplified ع- يجب ان يتم سحب العقاقير المهئة تدريجياً وطبقاً للبرتوكل لتجنب اعراض الأنسحاب التى قد تصدث من عدم اتباع بروتوكول سحب 